\title{
Diabetic and Prediabetic Profile of Patients in a Family Health Care Unit of Salvador, Northeastern Brazil
}

\author{
João Zallio Coelho1, Pedro Julião Zallio Coelho', Sanchela Raiane Pereira de Oliveira', \\ Alex Farias Soares'1, Jacqueline Novais Santana1, Paulo Ricardo Bacelar Macedo1, \\ Juliana Silveira de Freitas ${ }^{1}$, Danilo Guimarães Nogueira Andrade ${ }^{1}$, \\ Mirella Hansen de Almeida1,2, Denise Rosso Tenório Wanderley Rocha1, \\ Alberto Krayyem Arbex ${ }^{1,3}$ \\ ${ }^{1}$ Division of Endocrinology, IPEMED Medical School, São Paulo, Brazil \\ ${ }^{2}$ Visiting Physician, Joslin Diabetes Center, Harvard University, Boston, USA \\ ${ }^{3}$ Visiting Scientist, Harvard T. H. Chan School of Public Health, Harvard University, Boston, USA \\ Email: doutorjoaozallio@gmail.com.br
}

Received 13 December 2015; accepted 18 January 2016; published 21 January 2016

Copyright (C) 2016 by authors and Scientific Research Publishing Inc.

This work is licensed under the Creative Commons Attribution International License (CC BY). http://creativecommons.org/licenses/by/4.0/

c) (i) Open Access

\begin{abstract}
Diabetes Mellitus is one of the most prevalent diseases in the world. In Brazil, $8.7 \%$ of the population between 20 and 79 years of age has diabetes, estimating 11.6 million diabetics. It is commonly associated with other co-morbidities such as hypertension, dyslipidemia and obesity, which put these patients into a high cardiovascular risk profile. This study was performed using the medical records of enrolled population attending a Family Health Unit of Alto do Coqueirinho, Salvador, Northeastern Brazil, consisting of one doctor, one nurse, one dentist, one nursing technician and six community health workers. Medical records and data provided by the system of the Primary Care Information (SIAB), showed total of 2495 patients. Considering the prevalence morbidities in this population, hypertension was present in $9.8 \%$ of patients and Type 2 Diabetes in only $3.6 \%$. Since the prevalence of morbidities is the key indicator to the development of public health policies, it seems important a better knowledge on the prevalence rates of diabetes, prediabetes and its co-morbidities of this population. Future plans and projects for health professionals will be based on a consistent medical record.
\end{abstract}

\section{Keywords}

Diabetes, Prediabetes, Comorbidities, Family Health Unit

How to cite this paper: Coelho, J.Z., Coelho, P.J.Z., de Oliveira, S.R.P., Soares, A.F., Santana, J.N., Macedo, P.R.B., de Freitas, J.S., Andrade, D.G.N., de Almeida, M.H., Rocha, D.R.T.W. and Arbex, A.K. (2016) Diabetic and Prediabetic Profile of Patients in a Family Health Care Unit of Salvador, Northeastern Brazil. Open Journal of Endocrine and Metabolic Diseases, 6, 66-71. http://dx.doi.org/10.4236/ojemd.2016.61009 


\section{Introduction}

Diabetes Mellitus (DM) is a metabolic disorder characterized by hyperglycemia and commonly associated with acute and chronic complications. It is a chronic disease and its pathophysiology involves insulin secretion deficiency and peripheral insulin resistance [1].

The most common types of diabetes are type 1 Diabetes (DM1), which represents about $10 \%$ of all cases, and Type 2 Diabetes (DM2), which comprises about $90 \%$ of the cases [2]-[4].

DM2 shows an increase in its incidence in recent years. In Brazil, it is estimated a total of 11.6 million diabetics, representing $8.7 \%$ of the population aged from 20 to 79 years of age. In an international ranking, taking into account the estimated number of patients, Brazil already ranks fourth, behind China, India and the United States [5]-[7].

Due to its chronicity, DM is associated with micro and macrovascular complications of high morbidity and mortality, requiring continuous care, continuing education and support for prevention of acute and chronic complications [8] [9].

From the perspective of public health, DM is one of the leading causes of death in the world, being the 4th largest cause of death in this country. Adults with DM have two- to four-fold greater risk of developing cardiovascular disease (CVD), peripheral vascular disease and stroke than non-diabetic subjects. DM is also the most common cause of non-traumatic lower limb amputations, blindness and irreversible chronic kidney disease [9][12].

Despite the knowledge about the disease, its prevalence is constantly on the rise. The real capacity to prevent and to diagnose Type 2 Diabetes in the general population remains limited. However, it is known that individuals with impaired glucose tolerance (IGT) at fasting, preclinical stages of the disease, especially those with combined GJA and TDG are more likely to develop the disease and all its range of complications [13]-[16].

Diabetes prevention targets are to delay the onset of the disease, to preserve beta cell function and to prevent micro and macrovascular complications. As this is a progressive disease, patients at risk require positive changes in lifestyle (dieting and physical activity habits) associated with pharmacological treatment because pancreatic beta cells tend to progress to a state of partial or total failure years after the diagnose [17] [18].

The Family Health Program (PSF) started in 1994, now known as the Family Health Strategy. It was established in order to reorganize the healthcare model in Brazil, seeking to be the population's gateway to health services. By such logic, actions to ensure screening strategies, correct diagnosis, effective treatment and prevention of acute and chronic diseases, such as diabetes, would offer great contribution to the improvement of our health indicators [19] [20].

The aim of this study is to determine the prevalence of DM2 and prediabetes, to characterize the epidemiological profile of the population served by "Equipe Nova Esperança”, Family Health Unit of the Alto do Coqueirinho in the city of Salvador, Bahia, Northeastern Region of Brazil, and based on these results to offer better public health policies.

\section{Materials and Methods}

This study was conducted by analyzing the prevalence of Diabetes, prediabetes and other comorbidities in patients registered at the Family Health Unit named “Equipe Nova Esperança”, working at “Alto do Coqueirinho”, health district of Itapuã, Salvador, Northeastern Region of Brazil.

The study population was composed of 2495 patients. Clinical and epidemiological data were obtained from a questionnaire and medical records. Informed consent was obtained from all subjects.DM2 and prediabetes diagnosis was established according to WHO criteria.

Based on the questionnaire, only 150 patients were selected, 90 (60\%) of them with DM2 and 60 patients (40\%) with prediabetes.

Blood was sampled to measure fasting and stimulated glucose after 75 grams of anhydrous glucose dissolved in water, glycosylated hemoglobin (HbA1C) and random glucose.

For glucose and HbA1C measurement, fasting should be of 8 hours minimum in the absence of unequivocal hyperglycemia.

HbA1C was performed using a certified method by the National Glycohemoglobin Standardization Program and standardized by the Diabetes Control and Complications Trial. Random blood glucose test was confirmed with a second measurement in patients with classic symptoms of hyperglycemia or hyperglycemic crisis. 
In a second phase of the study data was collected, regarding the association of DM and prediabetes with other comorbidities.

To classify patients as overweight or obesity, body mass index (BMI) was used based on the WHO criteria: low BMI $\left(<18.5 \mathrm{~kg} / \mathrm{m}^{2}\right)$, normal weight $\left(18.5-24.9 \mathrm{~kg} / \mathrm{m}^{2}\right)$, overweight $\left(25-29.9 \mathrm{~kg} / \mathrm{m}^{2}\right)$, class I obesity (30 $\left.34.9 \mathrm{~kg} / \mathrm{m}^{2}\right)$, class II obesity $\left(35-39.9 \mathrm{~kg} / \mathrm{m}^{2}\right)$ and class III obesity $\left(\geq 40 \mathrm{~kg} / \mathrm{m}^{2}\right)$ [18].

\section{Results}

The population comprised 2495 individuals. Their clinical characteristics are shown in Table 1.

There was a higher prevalence of female patients in "Equipe Nova Esperança”: 1288 (51.6\%) than male 1207 (28.4\%). The higher prevalence of women in the enrolled population is also reflected in the greater number of female patients who attend medical appointments in the Family Health Unit.

Another important aspect seem in the group concerns the age. A total of 953 patients (38.2\%) aged 20 to 39 years old was found at the sample, representing a percentage of $38.2 \%$ of the total population.

Table 2 shows that ninety patients were identified DM2, which represents an incidence of $3.6 \%$ and 60 patients with prediabetes, an incidence of $2.4 \%$ of the population of "Equipe Nova Esperança" of the Family Health Unit Alto do Coqueirinho.

Hypertension had the highest incidence rates, with a total of 246 patients diagnosed, $9.8 \%$ of the study population.

Considering BMI index, $5.4 \%$ of patients were obese (BMI $>30 \mathrm{Kg} / \mathrm{m}^{2}$ ) and $2.7 \%$ were overweight (BMI between $25-30 \mathrm{Kg} / \mathrm{m}^{2}$ ). Other comorbities included $5.3 \%$ of dyslipidemia, and $0.6 \%$ of hypothyroidism.

Ninety patients with DM attended the government program name Hiperdia Program. Out of these, 54 patients (60.0\%) were female and 36 (40.0\%) were male. Regarding the age group, most patients were older than 60 years (40\%) (Table 3$)$.

Table 1. Clinical data of the study population, FHU Alto do Coqueirinho, Salvador, Brazil, 2015.

\begin{tabular}{ccc}
\hline GENDER & NUMBER & \% \\
\hline Female & 1288 & 51.6 \\
Male & 1207 & 48.4 \\
\hline AGE RANGE & & 0.2 \\
\hline 1 to 4 & 7 & 3.4 \\
5 to 6 & 85 & 1.7 \\
7 to 9 & 61 & 4.2 \\
10 to 14 & 105 & 10.8 \\
15 to 19 & 270 & 11.5 \\
20 to 39 & 287 & 38.2 \\
40 to 49 & 953 & 15.0 \\
50 to 59 & 374 & 9.0 \\
\hline 60 & 226 & 126 \\
\hline
\end{tabular}

Table 2. Comorbidities prevalence of the study population, FHU Alto do Coqueirinho, Salvador, Brazil, 2015.

\begin{tabular}{ccc}
\hline COMORBIDITY & NUMBER & \% \\
\hline Diabetes Mellitus & 90 & 3.6 \\
Prediabetes & 60 & 2.4 \\
Hypertension & 246 & 9.8 \\
Hypothyroidism & 15 & 0.6 \\
Dyslipidemia & 132 & 5.3 \\
Overweight & 69 & 2.7 \\
Obesity & 135 & 5.4 \\
\hline
\end{tabular}

Source: Data collected from primary care identification system, during the month of May, 2015. 
The most prevalent comorbidity in patients with DM2 was HBP, accounting for 51.6\% (66 patients) of all cases.

Dyslipidemia was present in $50.0 \%$ of patients. Obesity was the second most prevalent comorbidity, affecting $23.3 \%$ of patients. Incidence of overweight and hypothyroidism was $16.7 \%$ and $6.7 \%$ respectively (Table 4 ).

Sixty registered patients had prediabetes, 36 patients (60\%) were female and $24(40 \%)$ male. Regarding age, most prediabetic were in the age group of 50 to 59 years, representing a total of $40 \%$ (Table 5).

There was a similar prevalence among patients with diabetes who were in the age group of 20 - 39 years of age, and in the group of 40 to 49 years, representing age groups with a total of 12 patients each, a percentage of $20 \%$ of the general population.

The most prevalent comorbidity in patients with prediabetes was hypertension, present in $55 \%$ of patients with Type 2 DM, representing a total of 33 patients, resembling with prevalence in the diabetic population. Dyslipidemia was present in $45 \%$ of patients with prediabetes, and obesity was observed in $30 \%$ of patients and overweight in $20 \%$ of prediabetes population (Table 6). Hypothyroidism was not found in patients with prediabetes.

\section{Discussion}

The study showed a low prevalence of DM and prediabetes in Family Health Unit of the Alto do Coqueirinho.

Table 3. Social profile of patients with DM2, FHU Alto do Coqueirinho, Salvador, Brazil, 2015.

\begin{tabular}{ccc}
\hline GENDER & NUMBER & \% \\
\hline Female & 54 & 60.0 \\
Male & 36 & 40.0 \\
\hline AGE RANGE & & 10.0 \\
\hline 20 to 39 & 9 & 16.7 \\
40 to 49 & 15 & 33.3 \\
50 to 59 & 30 & 40.0 \\
\hline 60 & 36 & \\
\hline
\end{tabular}

Source: Data collected from primary care identification system, for the month of May of 2015.

Table 4. Prevalence of comorbidities in patients with Type 2 DM: data from the studied population, FHU Alto do Coqueirinho, Salvador, Brazil, 2015.

\begin{tabular}{ccc}
\hline COMORBIDITY & 66 & 51.6 \\
\hline Hypertension & 6 & 6.7 \\
Hypothyroidism & 45 & 50.0 \\
Dyslipidemia & 15 & 16.7 \\
Overweight & 21 & 23.3 \\
\hline
\end{tabular}

Source: Data collected from primary care identification system, for the month of May of 2015.

Table 5. Profile of patients with prediabetes, FHU Alto do Coqueirinho, Salvador, Brazil, 2015.

\begin{tabular}{|c|c|c|}
\hline \multicolumn{3}{|l|}{ GENDER } \\
\hline Female & 36 & 60.0 \\
\hline Male & 24 & 40.0 \\
\hline \multicolumn{3}{|c|}{ AGE RANGE } \\
\hline 10 to 19 & 3 & 5.0 \\
\hline 20 to 39 & 12 & 20.0 \\
\hline 40 to 49 & 12 & 20.0 \\
\hline 50 to 59 & 24 & 40.0 \\
\hline$>60$ & 6 & 15.0 \\
\hline
\end{tabular}

Source: Data collected from primary care identification system, for the month of May of 2015. 
Table 6. Association of comorbidities with prediabetes of the studied population, FHU Alto do Coqueirinho, Salvador, Brazil, 2015.

\begin{tabular}{ccc}
\hline Comorbidity & Number of patients & \% \\
\hline Hypertension & 33 & 55.0 \\
Hypothyroidism & 0 & 0.0 \\
Dyslipidemia & 27 & 45.0 \\
Overweight & 12 & 20.0 \\
Obesity & 18 & 30.0 \\
\hline
\end{tabular}

Source: Data collected from primary care identification system, during May, 2015.

Compared to other studies this prevalence was below Brazilian average rates.

Comorbidities such as hypertension, dyslipidemia, obesity, and overweight among patients with DM and prediabetes had a high prevalence.

Another important risk factor is the higher prevalence of diabetes in patients over the age of 60 , while the pre-diabetic state has a higher prevalence in patients aged over 50 years.

Although there is no consensus on the efficacy and the reduction of cardiovascular outcomes in patients with prediabetes, it is clear that changes in lifestyle, including improvements in eating habits, smoking cessation, exercise, associated or not to use medications, can have a positive impact in reducing the number of cases of Type 2 diabetic patients and their micro and macro vascular complications.

The prevalence of the diseases analyzed in the study is below the expected for the profile of the study population [10]. Probably there is an underreporting due to fault diagnosis and lack of more simplified notification methods for health professionals. Another important factor is the lack, in most cases, by health professionals of a Family Health Unit, the discussion of health indicators in the area where they are working. In addition, it is necessary matrix support teams, seeking to draw together goals and tracking health diagnoses.

\section{Conclusion}

It is essential for the health caregiver to know the epidemiological situation of the area where he/she works, in order to make the proper diagnosis of chronic diseases among that specific population. A better understanding of the health and disease patterns is from the area where they are working; the caregiver will have available elements to focus on achieving viable health goals, using the scientific knowledge available, applying evidencebased medicine, thus promoting the necessary interventions towards improving the health indicators and using them to guide their actions. Although the cost-effectiveness of intervention strategies should be further studied, measures in order to treat prediabetes should be considered with a view to preventing type DM and cardiovascular diseases.

\section{Acknowledgements}

The authors would like to thank IPEMED Brazil for supporting continuous research towards a better medical education in Brazil and abroad.

\section{References}

[1] Gross, J.L., Silveiro, S.P., Camargo, J.L., Reichelt, A.J. and Azevedo, M.J. de. (2002) Diabetes Melito: Diagnóstico, Classificação e Avaliação do Controle Glicêmico. Arquivos Brasileiros de Endocrinologia \& Metabologia, 46, 16-26. http://dx.doi.org/10.1590/S0004-27302002000100004

[2] Artilheiro, M.M.V. de S.A., Franco, S.C., Schulz, V.C. and Coelho, C.C. (2014) Quem são e como são tratados os pacientes que internam por diabetes mellitus no SUS? Saúde em Debate, 38, 210-224. http://dx.doi.org/10.5935/0103-1104.20140019

[3] Filha, C., Sousa, F.S., Nogueira, L.T. and Medina, M.G. (2014) Avaliação do controle de hipertensão e diabetes na Atenção Básica: Perspectiva de profissionais e usuários. Saúde em Debate, 38, 265-278.

[4] Barsaglini, R.A. and Canesqui, A.M. (2010) A alimentação e a dieta alimentar no gerenciamento da condição crônica do diabetes. Saúde e Sociedade, 19, 919-932. http://dx.doi.org/10.1590/S0104-12902010000400018 
[5] Silva, T.R., Feldmam, C., Lima, M.H.A., Nobre, M.R.C. and Domingues, R.Z.L. (2006) Controle de diabetes Mellitus e hipertensão arterial com grupos de intervenção educacional e terapêutica em seguimento ambulatorial de uma Unidade Básica de Saúde. Saúde e Sociedade, 15, 180-189. http://dx.doi.org/10.1590/S0104-12902006000300015

[6] Matos, L.N. de, Giorelli, G. de V., Saado, A. and Dias, C.B. (2011) Prevalence of Prediabetes in Patients with Metabolic Risk. Sao Paulo Medical Journal, 129, 300-308. http://dx.doi.org/10.1590/S1516-31802011000500004

[7] Passos, V.M. de A., Barreto, S.M., Diniz, L.M. and Lima-Costa, M.F. (2005) Type 2 Diabetes: Prevalence and Associated Factors in a Brazilian Community-The Bambuí Health and Aging Study. Sao Paulo Medical Journal, 123, 6671. http://dx.doi.org/10.1590/S1516-31802005000200007

[8] Torquato, M.T. da C.G., Junior, M., Magalhães, R., Viana, L.A.L., Souza, R.A.H.G. de, Lanna, C.M.M., Lucas, J.C.B., Bidurin, C. and Foss, M.C. (2003) Prevalence of Diabetes Mellitus and Impaired Glucose Tolerance in the Urban Population Aged 30 - 69 Years in Ribeirão Preto (São Paulo), Brazil. Sao Paulo Medical Journal, 121, 224-230. http://dx.doi.org/10.1590/S1516-31802003000600002

[9] Cercato, C., Mancini, M.C., Arguello, A.M.C., Passos, V.Q., Villares, S.M.F. and Halpern, A. (2004) Systemic Hypertension, Diabetes Mellitus, and Dyslipidemia in Relation to Body Mass Index: Evaluation of a Brazilian Population. Revista do Hospital das Clínicas, 59, 113-118. http://dx.doi.org/10.1590/S0041-87812004000300004

[10] Martins, I.S., Marucci, M. de F.N., Cervato, A.M., Okani, E.T., Mazzilli, R.N. and Casajus, M.I. (1996) Doenças cardiovasculares ateroscleróticas, dislipidemias, hipertensão, obesidade e diabetes melito em população da área metropolitana da região Sudeste do Brasil: II—Dislipidemias. Revista de Saúde Pública, 30, 75-84. http://dx.doi.org/10.1590/S0034-89101996000100010

[11] Schmidt, M.I., Duncan, B.B., Hoffmann, J.F., Moura, L. de, Malta, D.C. and Carvalho, R.M.S.V. de. (2009) Prevalência de diabetes e hipertensão no Brasil baseada em inquérito de morbidade auto-referida, Brasil, 2006. Revista de Saúde Pública, 43, 74-82. http://dx.doi.org/10.1590/S0034-89102009000900010

[12] Costa, J.S.D. da, Olinto, M.T.A., Assunção, M.C.F., Gigante, D.P., Macedo, S. and Menezes, A.M.B. (2006) Prevalência de Diabetes Mellitus em Pelotas, RS: Um estudo de base populacional. Revista de Saúde Pública, 40, 542545. http://dx.doi.org/10.1590/S0034-89102006000300025

[13] American Diabetes Association (2013) Diagnosis and Classification of Diabetes Mellitus. Diabetes Care, 36, S67-S74. http://dx.doi.org/10.2337/dc13-s067

[14] Wild, S., Roglic, G., Green, A., Sicree, R. and King, H. (2004) Global Prevalence of Diabetes. Estimates for the Year 2000 and Projections for 2030. Diabetes Care; 27, 1047-1053. http://dx.doi.org/10.2337/diacare.27.5.1047

[15] Francisco, P.M.S.B., Belon, A.P., Barros, M.B. de A., Carandina, L., Alves, M.C.G.P., Goldbaum, M. and Cesar, C.L.G. (2010) Diabetes auto-referido em idosos: Prevalência, fatores associados e práticas de controle. Cadernos de Saúde Pública, 26, 175-184. http://dx.doi.org/10.1590/S0102-311X2010000100018

[16] American Diabetes Association (2013) Diagnosis and classification of diabetes mellitus. Diabetes Care, 2, S11-S66. http://dx.doi.org/10.2337/dc13-s067

[17] Ministério da Saúde, Brasília (2006) Caderno de Atenção Básica no. 16: Diabetes mellitus.

[18] Godoy-Matos, A.F., et al. (2009) Diretrizes Brasileiras de Obesidade. Associação Brasileira para o Estudo da Obesidade e da Síndrome Metabólica (Abeso), 3ª ed, 11-12.

[19] Guedes, J. da S., Santos, R.M.B. dos and Di Lorenzo, R.A.V. (2011) A implantação do Programa de Saúde da Família (PSF) no Estado de São Paulo (1995-2002). Saúde e Sociedade, 20, 875-883. http://dx.doi.org/10.1590/S0104-12902011000400006

[20] Costa, C.H.L. da. (2000) Histórico sobre a implantação do PACS e PSF no estado do Pará. Revista Brasileira de Enfermagem, 53, 131-133. http://dx.doi.org/10.1590/S0034-71672000000700021 